\title{
OPTIMALISASI KECEPATAN PELAYANAN TERHADAP KEPUASAN \\ DAN LOYALITAS DENGAN KEPERCAYAAN WAJIB PAJAK SEBAGAI VARIABEL INTERVENING (Studi Pada Kantor UPPD Samsat Kabupaten Karanganyar)
}

\author{
Denny Mahendra \\ Staf Pengajar \\ Sekolah Tinggi Ilmu Ekonomi AUB Surakarta \\ e-mail : dennymahendr@gmail.com \\ Jarot Santosa \\ Staf Pengajar \\ Sekolah Tinggi Ilmu Ekonomi AUB Surakarta \\ Aris Tri Haryanto \\ Staf Pengajar \\ Sekolah Tinggi Ilmu Ekonomi AUB Surakarta
}

\begin{abstract}
The purpose of this study was to determine, analyze and prove empirically the effect of the influence of service speed on taxpayer trust and taxpayer satisfaction. The influence of taxpayer trust has a significant effect on taxpayer satisfaction. The effect of service speed on taxpayer loyalty. The influence of taxpayer trust has a significant effect on taxpayer loyalty. The population in this study which became the population was all taxpayers of Samsat UPPD Dipenda Central Java, Karanganyar Regency, amounting to around 2,733 people per week (data taken on March 21, 2020). In this study, a number of 100 samples were taken, so the research was a sample study by means of accidental random sampling. The use of accidental random sampling method is because every day the taxpayer always changes. Accidental random sampling is a technique for obtaining research data with respondents who can be met at the time the research was conducted. Service speed has a significant effect on taxpayer trust. Service speed has a significant effect on taxpayer satisfaction. Trust has a significant effect on taxpayer satisfaction. Service speed has a significant effect on taxpayer loyalty. Trust has a significant effect on taxpayer loyalty.
\end{abstract}

\begin{abstract}
ABSTRAK
Tujuan penelitian ini adalah untuk mengetahui, menganalisis dan membuktikan secara empiris pengaruh Pengaruh kecepatan pelayanan terhadap kepercayaan wajib pajak dan kepuasan wajib pajak. Pengaruh kepercayaan wajib pajak berpengaruh signifikan terhadap kepuasan wajib pajak. Pengaruh kecepatan pelayanan terhadap loyalitas wajib pajak. Pengaruh kepercayaan wajib pajak berpengaruh signifikan terhadap loyalitas Wajib pajak. Populasi dalam penelitian ini yang menjadi populasi adalah seluruh wajib pajak Samsat UPPD Dipenda Jawa Tengah Kabupaten Karanganyar yang berjumlah sekitar 2.733 orang per minggu (data diambil tanggal 21 Maret 2020). Dalam penelitian ini diambil sejumlah 100 sampel, sehingga penelitiannya merupakan penelitian sampel dengan cara accidental random sampling. Penggunaan metode accidental random sampling dikarenakan setiap hari wajib pajak selalu berganti. Accidental random sampling yaitu suatu teknik untuk mendapatkan data penelitian dengan responden yang dapat ditemui pada saat penelitian dilakukan. Kecepatan pelayanan berpengaruh signifikan terhadap kepercayaan wajib pajak
\end{abstract}


Kecepatan pelayanan berpengaruh signifikan terhadap kepuasan wajib pajak Kepercayaan berpengaruh signifikan terhadap kepuasan wajib pajak Kecepatan pelayanan berpengaruh signifikan terhadap loyalitas wajib pajak. Kepercayaan berpengaruh signifikan terhadap loyalitas wajib pajak.

Kata Kunci : kecepatan pelayanan, kepercayaan, kepuaswajib pajak dan loyalitas wajib pajak.

\section{PENDAHULUAN}

Penyelenggaraan pelayanan publik merupakan salah satu fungsi penting pemerintah disamping distribusi, regulasi, dan proteksi. Fungsi tersebut merupakan aktualisasi riil kontrak sosial yang diberikan masyarakat kepada pemerintah dalam konteks hubungan Principal-Agent. Berdasarkan kerangka kerja tersebut, pemerintah selanjutnya melakukan proses pengaturan alokasi sumberdaya publik dengan cara menyeimbangkan aspek penerimaan dan pengeluaran untuk memaksimalisasi penyediaan kebutuhan pelayanan kolektif.

Pelayanan publik oleh birokrasi publik merupakan salah satu perwujudan dari fungsi aparatur negara sebagai abdi masyarakat disamping abdi negara. Pelayanan publik adalah segala kegiatan pelayanan yang dilaksanakan oleh penyelenggara pelayanan publik sebagai upaya pemenuhan kebutuhan publik dan pelaksanaan ketentuan peraturan perundang-undangan (Mahmudi, 2015). Menurut Pasalong (2015), pelayanan pada dasarnya didefinisikan sebagai aktifitas seseorang, sekelompok dan/atau organisasi baik secara langsung maupun tidak langsung untuk memenuhi kebutuhan. Jadi dapat dikatakan bahwa dalam pelayanan terdapat dua aspek yaitu seseorang/organisasi dan pemenuhan kebutuhan. Sesuai dengan Undang-Undang Nomor 25 Tahun 2009 tentang Pelayanan Publik, Pelayanan publik adalah kegiatan atau rangkaian kegiatan dalam rangka pemenuhan kebutuhan pelayanan bagi setiap warga negara dan penduduk atas barang, jasa, dan/atau pelayanan administratif yang disediakan oleh penyelenggara pelayanan publik.

Tolok ukur untuk pengembangan pelayanan publik guna kepuasan masyarakat, terkait dengan Keputusan Menteri Pendayagunaan Aparatur Negara Nomor KEP/25/M.PAN/2014 salah satunya adalah kecepatan pelayanan. Kecepatan pelayanan merupakan target waktu pelayanan dapat diselesaikan dalam waktu yang telah ditentukan oleh unit penyelenggara pelayanan. Apabila dalam melayani masyarakat, kecepatan pelayanan dirasakan sesuai dengan persepsi yang diharapkan maka masyarakat akan merasakan kepuasan, sebaliknya apabila dalam pelayanan dirasakan terlalu lama, akan menimbulkan rasa ketidak puasan masyarakat. Penelitian berkaitan dengan kecepatan pelayanan dilakukan oleh Sani (2014); Jumiati (2016) dan Hermanto (2016) menyimpulkan adanya pengaruh positif dan signifikan kecepatan pelayanan terhadap kepuasan. Variabel kecepatan pelayanan sebagai variabel yang berdiri sendiri masih jarang dilakukan sehingga kecepatan pelayanan ini masih tergolong baru dalam penelitian. Kecepatan pelayanan merupakan salah satu bagian dari sub indikator kualitas pelayanan. Banyak peneliti yang masih menggunakan kualitas pelayanan terkait dengan loyalitas.

Pelayanan adalah proses pemenuhan kebutuhan melalui aktivitas orang lain secara langsung. Kecepatan pelayanan merupakan salah satu indikator yang ditetapkan oleh kantor pelayanan publik untuk mengukur kualitas pelayanan yang bertujuan untuk kepuasan masyarakat yang dapat meningkatkan kepercayaan masyarakat sehingga loyalitas terbentuk.

Tujuan pelayanan publik pada dasarnya adalah untuk memuaskan dan memenuhi kebutuhan sesuai dengan keinginan masyarakat pada umumnya. Untuk mencapai hal ini, diperlukan kualitas pelayanan yang terukur sesuai harapan dari masyarakat. Kualitas pelayanan publik merupakan tolak ukur untuk menentukan bagaimana loyalitas layanan publik di suatu lembaga penyedia layanan publik. Terkait kualitas pelayanan publik menurut pasalong (2015) dasarnya merupakan kata yang menyandang arti relatif bersifat abstrak, kualitas dapat digunakan untuk menilai atau menentukan tingkat penyesuaian suatu hal terhadap persyaratan atau spesifikasinya itu terpenuhi berarti kualitas suatu hal yang dimaksud dapat dikatakan baik, sebaliknya jika persyaratan tidak terpenuhi maka dapat dikatakan tidak baik. Secara teoritis, tujuan pelayanan publik pada dasarnya adalah untuk memuaskan masyarakat. Kepuasan dapat tercipta dari pengalaman dalam mengonsumsi jasa atau produk, jika 
lembaga dapat memberikan janji sesuai dengan yang diharapkan maka mereka akan merasa puas. Berbagai tingkat kepuasan dan ketidakpuasan setelah mengalami atau merasakan masing-masing jasa sesuai dengan sejauh mana harapan mereka terpenuhi atau terlampaui (Verriana dan Anshori, 2017). Dalam penelitian ini organisasi publik yang akan diteliti adalah Kantor Bersama Sistem Administrasi Manunggal di Bawah Satu Atap (SAMSAT). Kantor Bersama Samsat UPPD Dipenda Propinsi Jateng Kabupaten Karanganyar merupakan suatu wadah yang melaksanakan tugas secara bersama-sama dari 3 (tiga) instansi, yaitu Dinas Pendapatan Daerah, Direktorat Lalu Lintas Kepolisian Daerah, dan PT. Jasa Raharja (Persero) Cabang, yang berkewajiban memberikan pelayanan kepada masyarakat di bidang pendaftaran kendaraan bermotor, pembayaran Pajak Kendaraan Bermotor (PKB), pembayaran Bea Balik Nama Kendaraan Bermotor (BBNKB) dan pembayaran Sumbangan Wajib Dana Kecelakaan Lalu Lintas Jalan (SWDKLLJ).

Kantor Bersama Samsat UPPD Dipenda Propinsi Jateng Kabupaten Karanganyar di era reformasi ini telah banyak melakukan perubahan-perubahan secara mendasar terutama dalam hal pelayanan kepada masyarakat. Kecepatan pelayanan merupakan salah satu unsur dari kualitas pelayanan menjadi sorotan dari masyarakat. Paradigma baru dalam penyelenggaraan pemerintah yang sering disebut dengan "good governance" menuntut setiap aparatur harus dapat bertanggungjawab dan mempertanggungjawabkan segala sikap, perilaku, dan kebijakannya kepada publik. Perubahan paradigma baru tersebut oleh Badan Pengelola Pendapatan Daerah Propinsi Jawa Tengah UPPD Samsat Kabupaten Karanganyar, menggunakan standarisasi waktu kecepatan pelayanan yang diterapkan kepada setiap petugas dalam melayani wajib pajak. Standarisasi waktu kecepatan pelayanan untuk pajak ulang atau pengesahan selama 20 menit, kendaraan bermotor baru selama 50 menit, ganti nama lokal selama 50 menit, ganti nomor dari luar daerah selama 50 menit. Melalui standarisasi kecepatan layanan pajak kendaraan bermotor ini diharapkan dapat menumbuhkan kepercayaan, kepuasan dan loyalitas wajib pajak.

Dukungan masyarakat dalam hal ini wajib pajak dalam memberikan kepercayaan agar pelayanan dapat terwujud kecepatan pelayanan sesuai standar dengan datang sendiri membawa persyaratan sesuai ketentuan berlaku. Kepuasan dan loyalitas wajib pajak merupakan energi positif bagi petugas pelayanan untuk mewujudkan pelayanan yang berkualitas. Penelitian berkaitan dengan loyalitas dilakukan oleh Elrado dkk, (2014), Kumadji dan Yulianto (2014), Pangandaheng (2015), Adi dan Mulyanto (2015) yang menunjukkan kepuasan berpengaruh positif terhadap loyalitas. Berdasarkan latar belakang yang telah diuraikan diatas, maka penulis tertarik untuk melakukan penelitian tentang "OPTIMALISASI KECEPATAN PELAYANAN TERHADAP KEPUASAN DAN LOYALITAS DENGAN KEPERCAYAAN WAJIB PAJAK SEBAGAI VARIABEL INTERVENING (studi pada Kantor UPPD samsat Kabupaten Karanganyar)"

\section{METODE}

Penelitian mengambil lokasi penelitian di lingkungan Kantor Bersama Samsat UPPD Dipenda Provinsi Jateng Kabupaten Karanganyar. Obyek penelitian adalah wajib pajak pada Kantor Bersama Samsat UPPD Dipenda Propinsi Jateng Kabupaten Karanganyar. Populasi dalam penelitian ini yang menjadi populasi adalah seluruh wajib pajak Samsat UPPD Dipenda Jawa Tengah Kabupaten Karanganyar yang berjumlah sekitar 2733 orang per minggu (data diambil tanggal 21 Maret 2020). Dalam penelitian ini diambil sejumlah 100 sampel, sehingga penelitiannya merupakan penelitian sampel dengan cara accidental random sampling. Penggunaan metode accidental random sampling dikarenakan setiap hari wajib pajak selalu berganti. Accidental random sampling yaitu suatu teknik untuk mendapatkan data penelitian dengan responden yang dapat ditemui pada saat penelitian dilakukan. 
ANALISIS DAN PEMBAHASAN

Tabel 1. Variabel Kecepatan pelayanan

\begin{tabular}{|c|c|c|c|}
\hline No Butir & Corrected Item Total Correlation & $\mathrm{r}_{\text {kritis }}$ & Status \\
\hline 1 & 0,633 & 0,195 & Valid \\
\hline 2 & 0,564 & 0,195 & Valid \\
\hline 3 & 0,791 & 0,195 & Valid \\
\hline 4 & 0,687 & 0,195 & Valid \\
\hline 5 & 0,669 & 0,195 & Valid \\
\hline 6 & 0,658 & 0,195 & Valid \\
\hline \multicolumn{4}{|c|}{ Sumber: Data yang diolah, 2020} \\
\hline \multicolumn{4}{|c|}{ Tabel 2. Variabel Kepercayaan } \\
\hline No Butir & Corrected Item Total Correlation & $\mathrm{r}_{\text {kritis }}$ & Status \\
\hline 1 & 0,708 & 0,195 & Valid \\
\hline 2 & 0,745 & 0,195 & Valid \\
\hline 3 & 0,767 & 0,195 & Valid \\
\hline 4 & 0,801 & 0,195 & Valid \\
\hline 5 & 0,700 & 0,195 & Valid \\
\hline \multicolumn{4}{|c|}{ Sumber: Data yang diolah, 2020} \\
\hline \multicolumn{4}{|c|}{ Tabel 3. Variabel Kepuasan } \\
\hline No Butir & Corrected Item Total Correlation & $\mathrm{r}_{\text {kritis }}$ & Status \\
\hline 1 & 0,625 & 0,195 & Valid \\
\hline 2 & 0,586 & 0,195 & Valid \\
\hline 3 & 0,595 & 0,195 & Valid \\
\hline 4 & 0,682 & 0,195 & Valid \\
\hline 5 & 0,661 & 0,195 & Valid \\
\hline 6 & 0,682 & 0,195 & Valid \\
\hline
\end{tabular}

Sumber: Data yang diolah, 2020

Tabel 4. Variabel Loyalitas

\begin{tabular}{cccc}
\hline No Butir & Corrected Item Total Correlation & $\mathrm{r}_{\text {kritis }}$ & Status \\
\hline 1 & 0,559 & 0,195 & Valid \\
2 & 0,487 & 0,195 & Valid \\
3 & 0,509 & 0,195 & Valid \\
4 & 0,449 & 0,195 & Valid \\
5 & 0,551 & 0,195 & Valid \\
\hline
\end{tabular}


Tabel 5. Hasil Uji Reliabilitas

\begin{tabular}{llll}
\hline Item pertanyaan & $\begin{array}{l}\text { Alpha } \\
\text { Cronbach }\end{array}$ & Kriteria & Keterangan \\
\hline Kecepatan pelayanan $\left(\mathrm{X}_{1}\right)$. & 0,857 & & Reliabel \\
Kepercayaan $\left(\mathrm{X}_{2}\right)$ & 0,895 & Alpha Cronbach> & Reliabel \\
Kepuasan $\left(\mathrm{Y}_{1}\right)$ & 0,852 & 0,60 maka reliable & Reliabel \\
Loyalitas $\left(\mathrm{Y}_{2}\right)$ & 0,745 & & Reliabel \\
\hline
\end{tabular}

Sumber: Data yang diolah, 2020

\section{Hasil Analisis Jalur Persamaan 1}

Tabel 6. Hasil Analisis Persamaan I

\begin{tabular}{|c|c|c|c|c|c|c|}
\hline \multicolumn{7}{|c|}{ Coefficients } \\
\hline \multirow[b]{2}{*}{ Model } & & \multicolumn{2}{|c|}{$\begin{array}{c}\text { Unstandardized } \\
\text { Coefficients }\end{array}$} & $\begin{array}{l}\text { Standardized } \\
\text { Coefficients }\end{array}$ & \multirow[b]{2}{*}{$t$} & \multirow[b]{2}{*}{ Sig. } \\
\hline & & $\mathrm{B}$ & Std. Error & Beta & & \\
\hline & (Constant) & 8,282 & 1,535 & & 5,396 &, 000 \\
\hline & Kecepatan Pelayanan &, 522 & ,063 & ,640 & 8,242 &, 000 \\
\hline
\end{tabular}

a. Dependent Variable: Kepercayaan

Sumber : Data yang diolah, 2020

Dari hasil di atas maka dapat dijelaskan sebagai berikut:

$\beta_{1}=$ koefisien regresi Kecepatan pelayanan $\left(X_{1}\right)$ sebesar 0,640, hal ini menunjukkan bahwa variabel Kecepatan pelayanan $\left(X_{1}\right)$ berpengaruh positif terhadap Kepercayaan $\left(X_{2}\right)$. Hal ini berarti apabila Kecepatan pelayanan $\left(\mathrm{X}_{1}\right)$ lebih baik, maka Kepercayaan $\left(\mathrm{X}_{2}\right)$ akan meningkat secara signifikan.

\section{Hasil Analisis Jalur Persamaan 2}

Tabel 7. Hasil Analisis Jalur Persamaan 2

\begin{tabular}{|c|c|c|c|c|c|c|}
\hline \multicolumn{7}{|c|}{ Coefficients $^{\mathrm{a}}$} \\
\hline \multirow[b]{2}{*}{ Mode } & & \multicolumn{2}{|c|}{$\begin{array}{l}\text { Unstandardized } \\
\text { Coefficients }\end{array}$} & \multirow{2}{*}{$\begin{array}{c}\begin{array}{c}\text { Standardized } \\
\text { Coefficients }\end{array} \\
\text { Beta }\end{array}$} & \multirow[b]{2}{*}{$\mathrm{t}$} & \multirow[b]{2}{*}{ Sig. } \\
\hline & & B & Std. Error & & & \\
\hline \multirow[t]{3}{*}{1} & (Cons tant) & 9,652 & 1,781 & & 5,419 &, 000 \\
\hline & Kecepatan Pelayanan & ,317 &, 084 & ,375 & 3,779 &, 000 \\
\hline & Kepercayaan & ,368 & 103 & ,355 & 3,579 & ,001 \\
\hline
\end{tabular}

a. Dependent Variable: Kepuasan

Sumber : Data yang diolah, 2020

Dari hasil di atas maka dapat dijelaskan sebagai berikut: 
1) $\beta_{4}=$ koefisien regresi Kecepatan pelayanan $\left(X_{1}\right)$ sebesar 0,375 , hal ini menunjukkan bahwa variabel Kecepatan pelayanan $\left(\mathrm{X}_{1}\right)$ berpengaruh positif terhadap kepuasan $\left(\mathrm{Y}_{1}\right)$.

2) $\beta_{5}=$ koefisien regresi variabel Kepercayaan $\left(X_{2}\right)$ sebesar 0,355 , hal ini menunjukkan bahwa variabel Kepercayaan $\left(\mathrm{X}_{2}\right)$ berpengaruh positif terhadap kepuasan $\left(\mathrm{Y}_{1}\right)$

\section{Hasil Analisis Jalur Persamaan 3}

Tabel 8. Hasil Analisis Jalur Persamaan 3

\begin{tabular}{|c|c|c|c|c|c|c|}
\hline \multicolumn{7}{|c|}{ Coefficients $^{\mathrm{a}}$} \\
\hline \multirow[b]{2}{*}{ Mod } & & \multicolumn{2}{|c|}{$\begin{array}{c}\text { Unstandardized } \\
\text { Coefficients }\end{array}$} & $\begin{array}{c}\text { Standardized } \\
\text { Coefficients }\end{array}$ & \multirow[b]{2}{*}{$t$} & \multirow[b]{2}{*}{ Sig. } \\
\hline & & $\mathrm{B}$ & Std. Error & Beta & & \\
\hline & (Constant) & 6,762 & 1,251 & & 5,405 &, 000 \\
\hline & Kecepatan Pelayanan & ,286 & ,059 & ,425 & 4,849 &, 000 \\
\hline & Kepercayaan & ,331 & ,072 & 401 & 4,578 & ,000 \\
\hline
\end{tabular}

a. Dependent Variable: Loyalitas

Sumber : Data yang diolah, 2020

Dari hasil di atas maka dapat dijelaskan sebagai berikut:

1) $\quad \beta_{4}=$ koefisien regresi Kecepatan pelayanan $\left(X_{1}\right)$ sebesar 0,425 , hal ini menunjukkan bahwa variabel Kecepatan pelayanan $\left(\mathrm{X}_{1}\right)$ berpengaruh positif terhadap loyalitas $\left(\mathrm{Y}_{2}\right)$.

2) $\beta_{5}=$ koefisien regresi variabel Kepercayaan $\left(X_{2}\right)$ sebesar 0,401 , hal ini menunjukkan bahwa variabel Kepercayaan $\left(\mathrm{X}_{2}\right)$ berpengaruh positif terhadap loyalitas $\left(\mathrm{Y}_{2}\right)$.

\section{Uji t persamaan 1}

Kecepatan pelayanan $\left(\mathrm{X}_{1}\right)$ berpengaruh signifikan terhadap Kepercayaan $\left(\mathrm{X}_{2}\right)$ di Kabupaten Karanganyar, hal ini dapat dilihat dari nilai signifikansi yaitu $0,000<0,05$. Hipotesis pertama yang menyatakan Kecepatan pelayanan $\left(\mathrm{X}_{1}\right)$ berpengaruh signifikan terhadap Kepercayaan $\left(\mathrm{X}_{2}\right)$ Kantor UPPD samsat Kabupaten Karanganyar terbukti.

\section{Uji t persamaan 2}

1) Kecepatan pelayanan $\left(X_{1}\right)$ berpengaruh signifikan terhadap kepuasan $\left(Y_{1}\right)$ Kantor UPPD samsat Kabupaten Karanganyar, hal ini dapat dilihat dari nilai signifikansi yaitu $0,000<0,05$. Hipotesis kedua yang menyatakan Kecepatan pelayanan $\left(\mathrm{X}_{1}\right)$ berpengaruh signifikan terhadap kepuasan $\left(\mathrm{Y}_{1}\right)$ Kantor UPPD samsat Kabupaten Karanganyar terbukti.

2) Kepercayaan $\left(\mathrm{X}_{2}\right)$ berpengaruh signifikan terhadap kepuasan $\left(\mathrm{Y}_{1}\right)$ Kantor UPPD samsat Kabupaten Karanganyar, hal ini dapat dilihat dari nilai signifikansi yaitu $0,001<0,05$. Hipotesis ketiga yang menyatakan Kepercayaan $\left(\mathrm{X}_{2}\right)$ berpengaruh signifikan terhadap kepuasan $\left(\mathrm{Y}_{1}\right)$ Kantor UPPD samsat Kabupaten Karanganyar terbukti.

Uji t persamaan 3

1) Kecepatan pelayanan $\left(X_{1}\right)$ berpengaruh signifikan terhadap loyalitas $\left(Y_{2}\right)$ Kantor UPPD samsat Kabupaten Karanganyar, hal ini dapat dilihat dari nilai signifikansi yaitu $0,000<0,05$. Hipotesis keempat yang menyatakan Kecepatan pelayanan $\left(\mathrm{X}_{1}\right)$ berpengaruh signifikan terhadap loyalitas $\left(\mathrm{Y}_{2}\right)$ Kantor UPPD samsat Kabupaten Karanganyar terbukti.

2) Kepercayaan $\left(\mathrm{X}_{2}\right)$ berpengaruh signifikan terhadap loyalitas $\left(\mathrm{Y}_{2}\right)$ Kantor UPPD samsat Kabupaten Karanganyar, hal ini dapat dilihat dari nilai signifikansi yaitu $0,000<0,05$. Hipotesis kelima yang menyatakan Kepercayaan $\left(\mathrm{X}_{2}\right)$ berpengaruh signifikan terhadap loyalitas $\left(\mathrm{Y}_{2}\right)$ Kantor UPPD samsat Kabupaten Karanganyar terbukti. 
Uji F Persamaan 2

Tabel 9. Hasil Uji F Persamaan 2

ANOVA

\begin{tabular}{|c|c|c|c|c|c|c|}
\hline Model & & $\begin{array}{l}\text { Sum of } \\
\text { Squares }\end{array}$ & df & Mean Square & $\mathrm{F}$ & Sig. \\
\hline \multirow[t]{3}{*}{1} & Regression & 271,493 & 2 & 135,747 & 37,584 &, $000^{\mathrm{a}}$ \\
\hline & Residual & 350,347 & 97 & 3,612 & & \\
\hline & Total & 621,840 & 99 & & & \\
\hline
\end{tabular}

a. Predictors: (Constant), Kepercayaan, Kecepatan Pelayanan

b. Dependent Variable: Kepuasan

Sumber: Data yang diolah, 2020

Hasil uji secara serempak (Uji F) pada persamaan kedua diketahui besarnya nilai $\mathrm{F}=37,584$ signifikansi $0,000<0,05$, sehingga dapat disimpulkan secara bersama-sama Kecepatan pelayanan $\left(\mathrm{X}_{1}\right)$ dan Kepercayaan $\left(\mathrm{X}_{2}\right)$ mempengaruhi kepuasan $\left(\mathrm{Y}_{1}\right)$ di UPPD Samsat Kabupaten Karanganyar.

\section{Uji F Persamaan 3}

Tabel 10. Hasil Uji F Persamaan 3

ANOVA

\begin{tabular}{|ll|r|r|r|r|r|}
\hline \multicolumn{2}{|l|}{} & & \multicolumn{1}{c|}{ Sum of } & & & \\
Sodel & & Squares & df & Mean Square & F & \multicolumn{1}{c|}{ Sig. } \\
\hline 1 & Regression & 219,950 & 2 & 109,975 & 61,701 &, $000^{\mathrm{a}}$ \\
& Residual & 172,890 & 97 & 1,782 & & \\
& Total & 392,840 & 99 & & & \\
\hline
\end{tabular}

a. Predictors : (Constant), Kepercayaan, Kecepatan Pelayanan

b. Dependent Variable: Loyalitas

Sumber: Data yang diolah, 2020

Hasil uji secara serempak (Uji F) pada persamaan kedua diketahui besarnya nilai $\mathrm{F}=61,701$ signifikansi $0,000<0,05$, sehingga dapat disimpulkan secara bersama-sama Kecepatan pelayanan $\left(\mathrm{X}_{1}\right)$ dan Kepercayaan $\left(\mathrm{X}_{2}\right)$ mempengaruhi loyalitas wajib pajak $\left(\mathrm{Y}_{2}\right)$ UPPD samsat Kabupaten Karanganyar.

\section{Koefisien Determinasi $\left(\mathbf{R}^{2}\right)$ Total atau Varian Total}

Koefisien Determinasi $\left(\mathrm{R}^{2}\right)$ Total 1 diperoleh sebagai berikut:

Uji $\mathrm{R}^{2}$ persamaan 1 didapatkan hasil sebesar 0,409

$\mathrm{e}_{1}=\sqrt{1-\mathrm{R}_{1}{ }^{2}}=\sqrt{1-0,409}=\sqrt{0,591}=0,591$

Uji $\mathrm{R}^{2}$ Persamaan 2 didapatkan hasil sebesar 0,437

$\mathrm{e}_{2}=\sqrt{1-\mathrm{R}_{2}{ }^{2}}=\sqrt{1-0,437}=\sqrt{0,563}=0,7543$

Uji $\mathrm{R}^{2}$ Persamaan 3 didapatkan hasil sebesar 0,560

$e_{3}=\sqrt{1-R_{3}{ }^{2}}=\sqrt{1-0,560}=\sqrt{0,440}=0,6663$ 


$$
\begin{aligned}
\mathrm{R}^{2} \text { total } 1 & =1-\left(\mathrm{e}_{1}{ }^{2} \mathrm{xe}_{2}{ }^{2} \times \mathrm{e}_{3}{ }^{2}\right) \\
& =1-(0,591 \times 0,563)=1-0,3363=0,6637 \\
\mathrm{R}^{2} \text { total } 2 & =1-\left(\mathrm{e}_{1}{ }^{2} \times \mathrm{e}_{3}{ }^{2}\right) \\
& =1-(0,591 \times 0,440)=1-0,2600=0,7400
\end{aligned}
$$

Nilai $\mathrm{R}^{2}$ total sebesar 0,6637 artinya variabel kepuasan $\left(\mathrm{Y}_{1}\right)$ dan loyalitas $\left(\mathrm{Y}_{2}\right)$ dapat dijelaskan variabel Kecepatan pelayanan $\left(\mathrm{X}_{1}\right)$ dan kepercayaan $\left(\mathrm{X}_{2}\right)$ sebesar $66,37 \%$ dan sisanya sebesar 33,63\% dijelaskan oleh variabel lain diluar model. Nilai $\mathrm{R}^{2}$ total 2 sebesar 0,7400 artinya variabel loyalitas $\left(\mathrm{Y}_{2}\right)$ dapat dijelaskan variabel Kecepatan pelayanan $\left(\mathrm{X}_{1}\right)$ dan kepercayaan $\left(\mathrm{X}_{2}\right)$

\begin{tabular}{|c|c|c|c|c|c|}
\hline \multicolumn{6}{|c|}{ Correlations } \\
\hline & & $\begin{array}{l}\text { Kecepatan } \\
\text { Pelayanan }\end{array}$ & Kepercayaan & Kepuasan & Loyalitas \\
\hline \multirow[t]{3}{*}{ Kecepatan Pelayanan } & Pearson Correlation & 1 &, $640^{\star *}$ &, $602^{\star \star}$ &, $682^{\star x}$ \\
\hline & Sig. (2-tailed) & &, 000 &, 000 &, 000 \\
\hline & $\mathrm{N}$ & 100 & 100 & 100 & 100 \\
\hline \multirow[t]{3}{*}{ Kepercayaan } & Pearson Correlation & ,640** & 1 &, $595^{\star \star}$ & ,673** \\
\hline & Sig. (2-tailed) &, 000 & &, 000 &, 000 \\
\hline & $\mathrm{N}$ & 100 & 100 & 100 & 100 \\
\hline \multirow[t]{3}{*}{ Kepuasan } & Pearson Correlation & ,602** & ,595** & 1 & $826^{\star \star}$ \\
\hline & Sig. (2-tailed) &, 000 &, 000 & & 000 \\
\hline & $\mathrm{N}$ & 100 & 100 & 100 & 100 \\
\hline \multirow[t]{3}{*}{ Loyalitas } & Pearson Correlation & ,682** & $673^{\star *}$ &, $826^{\star \star}$ & 1 \\
\hline & Sig. (2-tailed) &, 000 &, 000 &, 000 & \\
\hline & $\mathrm{N}$ & 100 & 100 & 100 & 100 \\
\hline
\end{tabular}
sebesar 74,00\% dan sisanya sebesar 33,63\% dijelaskan oleh variabel lain diluar model.

\section{Analisis Koefisien Korelasi}

Tabel 11. Hasil Analisis Koefisien Korelasi

${ }^{* \star}$. Correlation is significant at the 0.01 level (2-tailed).

Sumber: Data yang diolah, 2020

a. Korelasi Kecepatan pelayanan $\left(\mathrm{X}_{1}\right)$ dengan Kepercayaan $\left(\mathrm{X}_{2}\right)$ di Kabupaten Karanganyar sebesar 0,640 dapat diartikan bahwa hubungan Kecepatan pelayanan $\left(\mathrm{X}_{1}\right)$ dengan Kepercayaan $\left(\mathrm{X}_{2}\right)$ adalah kuat.

b. Korelasi Kecepatan pelayanan $\left(\mathrm{X}_{1}\right)$ dengan kepuasan $\left(\mathrm{Y}_{1}\right)$ di Kabupaten Karanganyar sebesar 0,602 dapat diartikan bahwa hubungan Kecepatan pelayanan $\left(\mathrm{X}_{1}\right)$ dengan kepuasan $\left(\mathrm{Y}_{1}\right)$ adalah kuat.

c. Korelasi Kepercayaan $\left(\mathrm{X}_{2}\right)$ dengan kepuasan $\left(\mathrm{Y}_{1}\right)$ di Kabupaten Karanganyar sebesar 0,595 dapat diartikan bahwa hubungan Kepercayaan $\left(\mathrm{X}_{2}\right)$ dengan kepuasan $\left(\mathrm{Y}_{1}\right)$ adalah cukup kuat.

d. Korelasi Kecepatan pelayanan $\left(\mathrm{X}_{1}\right)$ dengan loyalitas $\left(\mathrm{Y}_{2}\right)$ di Kabupaten Karanganyar sebesar 0,682 dapat diartikan bahwa hubungan Kecepatan pelayanan $\left(\mathrm{X}_{1}\right)$ dengan loyalitas $\left(\mathrm{Y}_{2}\right)$ adalah kuat.

e. Korelasi Kepercayaan $\left(\mathrm{X}_{2}\right)$ dengan loyalitas $\left(\mathrm{Y}_{2}\right)$ di Kabupaten Karanganyar sebesar 0,826 dapat diartikan bahwa hubungan Kepercayaan $\left(\mathrm{X}_{2}\right)$ dengan loyalitas $\left(\mathrm{Y}_{2}\right)$ adalah kuat. 
Pengaruh Langsung, Tidak Langsung, dan Total Pengaruh

Tabel 12.

Pengaruh Langsung, Tidak Langsung dan Total Pengaruh

\begin{tabular}{lccc}
\hline \multicolumn{1}{c}{ Keterangan } & Langsung & $\begin{array}{c}\text { Pengaruh } \\
\text { Tidak } \\
\text { langsung }\end{array}$ & \multicolumn{1}{c}{ Total pengaruh } \\
\hline $\begin{array}{l}\text { Kecepatan pelayanan } \rightarrow \\
\text { kepuasan }\end{array}$ & $\mathrm{P}_{3}=0,375$ & & \\
$\begin{array}{l}\text { Kecepatan pelayanan } \rightarrow \\
\text { loyalitas }\end{array}$ & $\mathrm{P}_{4}=0,425$ & & \\
$\begin{array}{l}\text { Kecepatan pelayanan } \rightarrow \\
\text { Kepercayaan } \rightarrow \text { kepuasan }\end{array}$ & & $\mathrm{P}_{1} \times \mathrm{P}_{7}=$ & $\mathrm{P}_{4}+\left(\mathrm{P}_{1} \times \mathrm{P}_{7)}=\right.$ \\
& & $0,640 \times 0,355=$ & $0,375+0,227=0,602$ \\
Kecepatan pelayanan $\rightarrow$ & & 0,227 & \\
Kepercayaan $\rightarrow$ loyalitas & & $\mathrm{P}_{2} \times \mathrm{P}_{7}=$ & $\mathrm{P}_{5}+\left(\mathrm{P}_{2} \times \mathrm{P}_{7}=\right.$ \\
& $0,640 \times 0,401=$ & $0,425+0,257=0,682$ \\
\hline
\end{tabular}

Sumber: Data yang diolah, 2020

Hasil analisis jalur secara lengkap dalam penelitian ini dapat dijelaskan secara rinci pengaruh antar variabel penelitian pada gambar berikut ini.

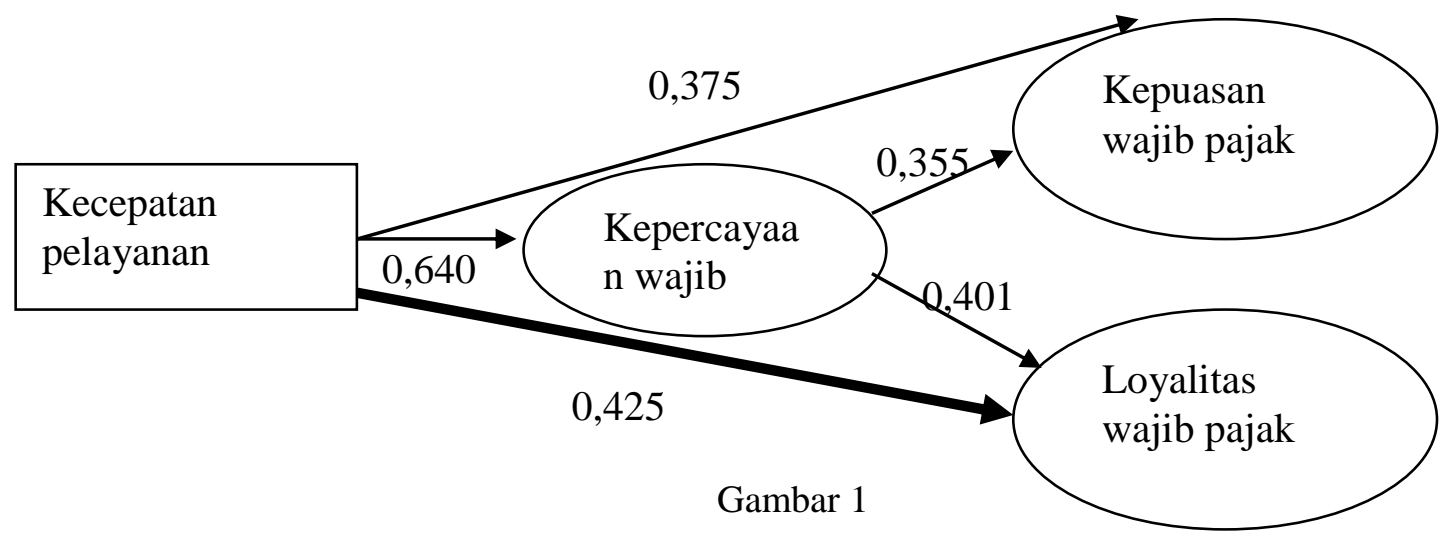

\section{Sobel Test}

Pengaruh Kecepatan pelayanan terhadap kepuasan wajib pajak dengan dimediasi kepercayaan

Pengujian hipotesis mediasi dapat dilakukan dengan prosedur yang dikembangkan oleh Sobel (1982) dan dikenal dengan Uji Sobel (Sobel Test). Uji Sobel ini dilakukan dengan cara menguji kekuatan pengaruh tidak langsung variabel independen $(\mathrm{X})$ kepada variabel dependen $(\mathrm{Y})$ melalui variabel intervening $(\mathrm{M})$. Pengaruh tidak langsung $\mathrm{X}$ ke $\mathrm{Y}$ melalui $\mathrm{M}$ dihitung dengan cara mengalikan jalur $X \rightarrow M$ (a) dengan jalur $M \rightarrow Y(\mathbf{b})$ atau ab. Jadi koefisien $\mathbf{a b}=(\mathbf{c}-\mathbf{c} ')$, di mana $\mathbf{c}$ adalah pengaruh $\mathrm{X}$ terhadap $\mathrm{Y}$ tanpa mengontrol $\mathrm{M}$, sedangkan c' adalah koefisien pengaruh $\mathrm{X}$ terhadap Y setelah mengontrol M.

Standar error koefisien a dan $\mathbf{b}$ ditulis dengan $\mathbf{S a}$ dan $\mathbf{S b}$, besarnya standar error tidak langsung (indirect effect) Sab dihitung dengan rumus berikut ini :

$$
S a b=\sqrt{\mathrm{b}^{2} \mathrm{~S}_{\mathrm{a}}^{2}+\mathrm{a}^{2} \mathrm{~S}_{\mathrm{b}}^{2}+\mathrm{S}_{\mathrm{a}}^{2} \mathrm{~S}_{\mathrm{b}}^{2}}
$$


Untuk menguji signifikansi pengaruh tidak langsung, maka kita perlu menghitung nilai t dari koefisien ab dengan rumus sebagai berikut :

$$
t_{\text {hitung }}=\frac{a b}{S a b}
$$

Nilai t hitung ini dibandingkan dibandingkan dengan nilai $t$ tabel dan jika nilai $t$ hitung lebih besar dari nilai $\mathrm{t}$ tabel maka dapat disimpulkan bahwa terjadi pengaruh mediasi. Berdasarkan tabel IV.18 dan tabel IV.19 pengaruh mediasi dari kepercayaan untuk variabel kecepatan pelayanan terhadap kepuasan dihitung sebagai berikut:

$$
\begin{aligned}
& S a b=\sqrt{\mathrm{b}^{2} \mathrm{~S}_{\mathrm{a}}{ }^{2}+\mathrm{a}^{2} \mathrm{~S}_{\mathrm{b}}{ }^{2}+\mathrm{S}_{\mathrm{a}}{ }^{2} \mathrm{~S}_{\mathrm{b}}{ }^{2}} \\
& S a b=\sqrt{(0,355)^{2}(0,063)^{2}+(0,640)^{2}(0,103)^{2}+(0,063)^{2}(0,103)^{2}} \\
& S a b=\sqrt{0,1260 \times 0,0040+0,4049 \times 0,0106+0,0040 \times 0,0106} \\
& S a b=\sqrt{0,0005+0,0040+0,0004} \\
& S a b=\sqrt{0,0049} \\
& S a b=0,0699
\end{aligned}
$$

Untuk menguji signifikansi pengaruh tidak langsung, maka kita perlu menghitung nilai $t$ dari koefisien ab dengan rumus sebagai berikut :

$$
\begin{aligned}
& \mathrm{t}_{\text {hitung }}=\frac{a b}{S a b} \\
& \mathrm{t}_{\text {hitung }}=\frac{0,640 \times 0,355}{0,0699}=\frac{0,2272}{0,0699}=3,25
\end{aligned}
$$

Nilai t hitung sebesar 3,25 dibandingkan dibandingkan dengan nilai t tabel dari 100 data $(\mathrm{t}$ tabel $=1,645$ ) diperoleh nilai $t$ hitung lebih besar dari nilai $t$ tabel maka dapat disimpulkan bahwa terjadi pengaruh mediasi variabel kepercayaan terhadap kepuasan wajib pajak

\section{Pengaruh Kecepatan pelayanan terhadap loyalitas wajib pajak dengan dimediasi kepercayaan}

Pengujian hipotesis mediasi dapat dilakukan dengan prosedur yang dikembangkan oleh Sobel (1982) dan dikenal dengan Uji Sobel (Sobel Test). Uji Sobel ini dilakukan dengan cara menguji kekuatan pengaruh tidak langsung variabel independen $(\mathrm{X})$ kepada variabel dependen $(\mathrm{Y})$ melalui variabel intervening $(\mathrm{M})$. Pengaruh tidak langsung $\mathrm{X}$ ke $\mathrm{Y}$ melalui $\mathrm{M}$ dihitung dengan cara mengalikan jalur $X \rightarrow M(\mathbf{a})$ dengan jalur $M \rightarrow Y(\mathbf{b})$ atau $\mathbf{a b}$. Jadi koefisien $\mathbf{a b}=(\mathbf{c}-\mathbf{c} ')$, di mana $\mathbf{c}$ adalah pengaruh $\mathrm{X}$ terhadap $\mathrm{Y}$ tanpa mengontrol $\mathrm{M}$, sedangkan c' adalah koefisien pengaruh $\mathrm{X}$ terhadap Y setelah mengontrol $\mathrm{M}$.

Standar error koefisien a dan $\mathbf{b}$ ditulis dengan $\mathbf{S a}$ dan $\mathbf{S b}$, besarnya standar error tidak langsung (indirect effect) Sab dihitung dengan rumus berikut ini :

$$
S a b=\sqrt{\mathrm{b}^{2} \mathrm{~S}_{\mathrm{a}}{ }^{2}+\mathrm{a}^{2} \mathrm{~S}_{\mathrm{b}}{ }^{2}+\mathrm{S}_{\mathrm{a}}{ }^{2} \mathrm{~S}_{\mathrm{b}}{ }^{2}}
$$

Untuk menguji signifikansi pengaruh tidak langsung, maka kita perlu menghitung nilai t dari koefisien ab dengan rumus sebagai berikut :

$$
\mathrm{t}_{\text {hitung }}=\frac{a b}{S a b}
$$

Nilai $t$ hitung ini dibandingkan dibandingkan dengan nilai $t$ tabel dan jika nilai $t$ hitung lebih besar dari nilai $\mathrm{t}$ tabel maka dapat disimpulkan bahwa terjadi pengaruh mediasi. Berdasarkan tabel IV.18 dan tabel IV.19 pengaruh mediasi dari kepercayaan untuk variabel kecepatan pelayanan terhadap kepuasan dihitung sebagai berikut. 


$$
\begin{aligned}
& S a b=\sqrt{\mathrm{b}^{2} \mathrm{~S}_{\mathrm{a}}{ }^{2}+\mathrm{a}^{2} \mathrm{~S}_{\mathrm{b}}{ }^{2}+\mathrm{S}_{\mathrm{a}}{ }^{2} \mathrm{~S}_{\mathrm{b}}{ }^{2}} \\
& S a b=\sqrt{(0,355)^{2}(0,401)^{2}+(0,640)^{2}(0,072)^{2}+(0,401)^{2}(0,072)^{2}} \\
& S a b=\sqrt{0,1260 \times 0,1608+0,4049 \times 0,0052+0,01608 \times 0,0052} \\
& S a b=\sqrt{0,0203+0,0021+0,0008} \\
& S a b=\sqrt{0,0232} \\
& S a b=0,1524
\end{aligned}
$$

Untuk menguji signifikansi pengaruh tidak langsung, maka kita perlu menghitung nilai t dari koefisien ab dengan rumus sebagai berikut :

$$
\begin{aligned}
& \mathrm{t}_{\text {hitung }}=\frac{a b}{S a b} \\
& \mathrm{t}_{\text {hitung }}=\frac{0,640 \times 0,355}{0,1524}=\frac{0,2272}{0,1524}=1,491
\end{aligned}
$$

Nilai t hitung sebesar 3,25 dibandingkan dibandingkan dengan nilai t tabel dari 100 data $(\mathrm{t}$ tabel=1,645) diperoleh nilai $t$ hitung lebih besar dari nilai $t$ tabel maka dapat disimpulkan bahwa tidak terjadi pengaruh mediasi variabel kepercayaan terhadap loyalitas wajib pajak

\section{PEMBAHASAN}

\section{Pengaruh kecepatan pelayanan terhadap kepuasan wajib pajak}

Penggunaan variabel intervening kepercayaan dalam rangka peningkatan kepuasan untuk variabel kecepatan pelayanan adalah tidak efektif, karena pengaruh tidak langsung menghasilkan pengaruh yang lebih kecil dari pengaruh langung. Hasil ini mendukung hasil penelitian sebelumnya yang dilakukan Sani (2014); Jumiati (2016) dan Hermanto (2016) menunjukkan kecepatan pelayanan berpengaruh positif signifikan terhadap kepuasan.

Upaya untuk meningkatkan kepuasan untuk variabel kecepatan pelayanan yaitu dengan cara:

a. UPPD SAMSAT Kabupaten Karanganyar menerapkan standarisasi proses pelayanan pengurusan pajak kendaraan bermotor

b. Proses pengurusan perpajakan kendaraan bermotor berjalan sesuai dengan alur pelayanan yang sudah ditentukan

c. Kecepatan proses pelayanan pajak kendaraan bermotor sesuai harapan wajib pajak

d. Samsat Keliling ataupun layanan Samsat Cepat sangat memberi kemudahan bagi wajib pajak dalam melakukan pajak ulang

$e$. Wajib pajak yang mengalami kesulitan saat melakukan perpajakan mendapatkan penanganan yang baik

f. Keluhan-keluhan yang ada dari wajib pajak mendapatkan perhatian khusus dan solusi dari petugas yang menangani

Adanya kecepatan pelayanan terhadap wajib pajak wajib pajak, maka menumbuhkan kepuasan wajib pajak

\section{Pengaruh kecepatan pelayanan terhadap loyalitas wajib pajak}

Penggunaan variabel intervening kepercayaan dalam rangka peningkatan loyalitas wajib pajak untuk variabel kecepatan pelayanan adalah tidak efektif, karena pengaruh tidak langsung menghasilkan pengaruh yang lebih kecil dari pengaruh langung. Hasil ini mendukung hasil penelitian sebelumnya yang dilakukan Hutama (2015) menunjukkan kecepatan pelayanan terhadap minat loyalitas. 
Upaya untuk meningkatkan loyalitas untuk variabel kecepatan pelayanan yaitu dengan cara:

a. UPPD SAMSAT Kabupaten Karanganyar menerapkan standarisasi proses pelayanan pengurusan pajak kendaraan bermotor guna menjaga loyalitas wajib pajak

b. Untuk meningkatkan loyalitas wajib pajak maka proses pengurusan perpajakan kendaraan bermotor harus berjalan sesuai dengan alur pelayanan yang sudah ditentukan

c. Untuk loyalitas wajib pajak dapat terjaga maka kecepatan proses pelayanan pajak kendaraan bermotor sesuai harapan wajib pajak

d. Samsat Keliling ataupun layanan Samsat Cepat sangat memberi kemudahan bagi wajib pajak dalam melakukan pajak ulang

$e$. Untuk menjaga loyalitas maka bagi wajib pajak yang mengalami kesulitan saat melakukan perpajakan harus mendapatkan penanganan yang baik

Keluhan-keluhan yang ada dari wajib pajak harus mendapatkan perhatian khusus dan solusi dari petugas yang menangani.

\section{KESIMPULAN DAN SARAN}

1. Hasil dari penelitian ini menunjukkan bahwa :

a. Kecepatan pelayanan berpengaruh signifikan terhadap kepercayaan wajib pajak

b. Kecepatan pelayanan berpengaruh signifikan terhadap kepuasan wajib pajak

c. Kepercayaan berpengaruh signifikan terhadap kepuasan wajib pajak

d. Kecepatan pelayanan berpengaruh signifikan terhadap loyalitas wajib pajak

e. Kepercayaan berpengaruh signifikan terhadap loyalitas wajib pajak

2. Hasil analisis jalur menunjukkan bahwa:

a. Peningkatan kepuasan wajib pajak lebih efektif melalui jalur langsung, karena hasil pengaruh langsung lebih besar dibandingkan pengaruh tidak langsung.

b. Peningkatan loyalitas wajib pajak lebih efektif melalui jalur langsung, karena hasil pengaruh langsung lebih besar dibandingkan pengaruh tidak langsung.

\section{Saran}

1. Dalam meningkatkan kepuasan wajib pajak maupun loyalitas wajib pajak maka lebih mengutamakan variabel kecepatan pelayanan secara langsung karena memiliki nilai pengaruh yang lebih dominan dibanding menggunakan intervening. Hal ini yang dapat dilakukan untuk meningkatkan dengan cara:

a. Kecepatan proses pelayanan pajak kendaraan bermotor sesuai harapan wajib pajak

b. Samsat Keliling ataupun layanan Samsat Cepat sangat memberi kemudahan bagi wajib pajak dalam melakukan pajak ulang

c. Wajib pajak yang mengalami kesulitan saat melakukan perpajakan mendapatkan penanganan yang baik

2. Penelitian mendatang agar mengganti variabel yang ada atau menambahkan variabel misalnya adanya variabel ketepatan pelayanan dan kenyamanan pelayanan serta memperluas lingkup penelitian.

Penelitian yang akan datang untuk memasukkan variabel intervening yang lain karena variabel kepercayaan tidak tepat dalam memediasi di dalam penelitian ini.

\section{DAFTAR PUSTAKA}

Andriyani, dkk Hafied Cangara, Rhiza S. Sadjad (2014). Penggunaan Teknologi Informasi Online Dalam Kecepatan Pelayanan Dan Pengamanan Pada Bank Bca Makassar (Sebuah Studi Komunikasi Organisasi).

Purwa dan Ardani (s0188). E-Jurnal Manajemen Unud, Vol. 7, No. 1, 2018: hal.192-220 ISSN : 2302-8912 
As'ad, Mohamad. 2015. Psikologi Industri. Liberty. Yogyakarta.

Atmosoeprapto, K. 2014. Produktivitas Aktualisasi Budaya Institusi : Mewujudkan Organisasi yang Efektif dan Efisien Melalui SDM Berdaya. Elex Media Komputindo. Jakarta.

Beach, Dale S. 2015. The management of People at Work, Mac Milian. New York

Creswell, John W. 2017. Research Design Pendekatan Kualitatif, Kuantitatif, dan. Mixed. Pustaka Pelajar. Yogyakarta.

Dharma, Surya.dan Haedar Akib. 2015. The Influence of Job Satisfaction on Work Performance: a Theoretical Approach. Usahawan. No. 2. TH XXXIV. hal. 30-33

Fauzi, Cholid (2015). Pengaruh Kecepatan pelayanan Terhadap Efektivitas Sistem Informasi. Prosiding. Seminar Nasional Aplikasi Teknologi Informasi (SNATi). ISSN: 1907 5022. Yogyakarta, 6 Juni 2015

Gautama dan Arfan (2015). Pengaruh Kepuasan Kerja, Profesionalisme, Dan Penerapan Teknologi Informasi Terhadap Loyalitas Auditor (Studi Pada Kantor Bpk Ri Perwakilan Provinsi Aceh). JURNAL TELAAH \& RISET AKUNTANSI. ISSN 1693-3397. Vol. 3. No. 2. Juli 2015. Hal. 195-205

Ghozali, Imam. 2016. Aplikasi Analisis Multivariate dengan SPSS. Badan Penerbit Universitas Diponegoro. Semarang

Gibson,. Ivancovich, dan Donelly 2015. Manajemen Sumber Daya Manusia. Terjemahan. Salemba Empat Jakarta

Gujarati, Damodar. 2016. Dasar-Dasar Ekonometrika. Erlangga. Jakarta.

Hasibuan, S,P. Malayu, 2015, Manajemen Sumber Daya Manusia, PT. Bumi Aksara, Jakarta

Hessel, Nogi Tangkalisan. 2015. Manajemen Publik. Grasindo. Jakarta.

Hutama (2015). Pengaruh Kecepatan Pelayanan, Kenyamanan Lokasi, Dan Persepsi Harga Terhadap Nilai Wajib pajak Serta Dampaknya Pada Minat Loyalitas.Skripsi. Undip. Semarang 
Indrias, Win Susilo Hari. 2014. Pengaruh Gaya Kepemimpinan dan Kecepatan pelayanan Terhadap Loyalitas Wajib pajak Melalui Kepuasan Kerja Sebagai Variabel Intervening Studi Kasus Pada Kantor Pelayanan Pajak Pratama Ruteng. Jurnal MIX, Volume IV, No. 1, Febuari 2014. Hal 70-82

Karsiati Dan Maskudi (2014). Pengaruh Kecepatan pelayanan , Teknologi Informasi Dan Sistem Informasi Akuntansi Manajemen Dalam Meningkatkan Loyalitas Manajerial. Jurnal Media Ekonomi Dan Manajemen ISSN : 0854-1442. Vol. 29 No. 1 Januari 2014. Hal 59-67

Kuncoro, Mudrajad, 2016, Metode Kuantitatif: Teori dan Aplikasi untuk Bisnis dan Ekonomi, Edisi I, AMP YKPN, Yogyakarta

Miller, 2015. Manajemen Era Baru, Beberapa pandangan Manajemen Budaya Institusi Modern, Penerbit Airlangga, Jakarta

Moenir, 2018. Manajemen Pelayanan Umum di Indonesia. PT Bumi Aksara. Jakarta

Musanef. 2015. Manajemen Kewajib pajakan di Indonesia. PT. Gunung Agung. Jakarta.

Prawirosentono, Suyadi. 2015. Kebijakan Loyalitas Karyawan, BPFE, Yogyakarta.

Sarwono. 2015. Analisis Jalur untuk Riset Bisnis dengan SPSS. Andi Offset. Yogyakarta.

Sugiyono, 2017. Metode Penelitian Bisnis. Alfabeta. Bandung.

Sumarlin, Tantik. (2015). Pengaruh Budaya Dan Teknologi Komputer Terhadap Kepuasan Kerja Dengan Sistem Informasi Sebagai Variabel Intervening Di Kabupaten Semarang. Jurnal KOMPAK. ISSN.1979-116X. Vol.8 No.1 April 2015. Hal 32-40. 